\title{
Effects of cryotherapy methods on circulatory, metabolic, inflammatory and neural properties: a systematic review
}

\author{
Efeitos dos métodos de crioterapia sobre propriedades circulatórias, \\ metabólicas, inflamatórias e neurais: uma revisão sistemática
}

\author{
Bruno Freire $^{[a]}$, Jeam Geremia ${ }^{[b]}$, Bruno Manfredini Baroni ${ }^{[c]}$, Marco Aurélio Vaz ${ }^{[b] *}$ \\ [a] Pontifícia Universidade Católica do Rio Grande do Sul (PUCRS), Porto Alegre, RS, Brazil \\ [b] Universidade Federal do Rio Grande do Sul (UFRGS), Porto Alegre, RS, Brazil \\ [c] Universidade Federal das Ciências da Saúde de Porto Alegre (UFCSPA), Porto Alegre, RS, Brazil
}

\begin{abstract}
Introduction: The cooling therapy (cryotherapy) is commonly used in clinical environmental for the injuries treatment according to its beneficial effects on pain, local inflammation and the recovery time of patients. However, there is no consensus in the literature about the effects of cryotherapy in the physiological reactions of affected tissues after an injury. Objective: To realize a systematic review to analyze the cryotherapy effects on circulatory, metabolic, inflammatory and neural parameters. Materials and methods: A search was performed in PubMed, SciELO, PEDro and Scopus databases following the eligibility criteria. Included studies were methodologically assessed by PEDro scale. Results: 13 original studies were selected and presented high methodological quality. Discussion: The cryotherapy promotes a significant decrease in blood flow, in venous capillary pressure, oxygen saturation and hemoglobin (only for superficial tissues) and nerve conduction velocity. However, the effect of cryotherapy on the concentration of inflammatory substances induced by exercise, as the creatine kinase enzyme and myoglobin, remains unclear. Conclusion: The physiological reactions to the cryotherapy application are favorable to the use of this therapeutic tool in inflammatory treatment and pain decrease, and demonstrate its importance in the neuromuscular system injuries rehabilitation.
\end{abstract}

Keywords: Cryotherapy. Blood flow. Oxygen saturation. Inflammation. Pain.

*BF: Msc, e-mail: freire.brunobolla@hotmail.com

JG: Msc, e-mail: jeam_geremia@hotmail.com

BMB: PhD, e-mail:bmbaroni@yahoo.com.br

MAV: PhD, e-mail: marco.vaz@ufrgs.br 


\section{Resumo}

Introdução: A terapia por meio do frio (crioterapia) é comumente utilizada no meio clínico para o tratamento de lesões em função de seus efeitos benéficos sobre a dor, a inflamação local e o tempo de recuperação dos pacientes. No entanto, não existe um consenso na literatura acerca dos efeitos da crioterapia nas reações fisiológicas de tecidos comprometidos após uma lesão. Objetivo: Realizar uma revisão para analisar os efeitos da aplicação de crioterapia sobre parâmetros circulatórios, metabólicos, inflamatórios e neurais. Materiais $\boldsymbol{e}$ métodos: Foi realizada uma revisão sistemática com busca nas bases de dados Pubmed, Scielo, PEDro e Scopus segundo os critérios de elegibilidade. Os estudos selecionados foram avaliados metodologicamente pela escala PEDro. Resultados: 13 estudos originais foram selecionados e que apresentaram alta qualidade metodológica. Discussão: A crioterapia promove uma significativa redução do fluxo sanguíneo, da pressão nos capilares venosos, da saturação de oxigênio e hemoglobina (apenas em tecidos superficiais)e da velocidade de condução neural. Contudo, o efeito do resfriamento tecidual sobre a concentração de substâncias inflamatórias induzidas pelo exercício, como a enzima creatina quinase e a mioglobina, permanece incerto. Conclusão: As respostas fisiológicas à aplicação da crioterapia são favoráveis ao uso desse recurso terapêutico no tratamento de processos inflamatórios e minimização de quadros álgicos, e demonstra sua importância na reabilitação de lesões do sistema neuromuscular.

Palavras-chave: Crioterapia. Fluxo sanguíneo. Saturação de oxigênio. Inflamação. Dor.

\section{Introduction}

Cryotherapy is one of the simplest and oldest therapeutic techniques used in physical rehabilitation (1). It involves the cooling of a target tissue to promote a decrease in local metabolism and to reduce injury symptoms, aiding the healing process (2). The common use of cryotherapy is related to the easiness of use.

The structural integrity of a tissue is affected after an injury. As an example, the rupture of the cellular membrane may lead, in some cases, to cellular death, which characterizes the primary event of the injury process, commonly denominated the primary lesion (3). A physiological response from enzymatic and metabolic mechanisms is activated in order to restore the integrity of the injured area. This second phase (secondary injury) is characterized by oxidative stress (4). The impairment of blood vessels decreases oxidative support and this ischemic period can cause the death of healthy cells in adjacent area of the injured site (3). In this context, tissue cooling is commonly used after injuries in order to decrease negative effects caused by secondary cell hypoxia (5). This cooling decreases the metabolic activity in damaged tissues and promotes survival of tissues subjected to an environment with low oxygen supply (6).

Treatment with tissue cooling seems to have the ability to decrease oxidative damages caused by inflammatory response (7). Previous studies observed a decrease in blood flow to $50 \%$ of the basal blood supply (8) secondary to local vasoconstriction (9). This is a mechanism that reduces pro-inflammatory substances that appear in blood circulation of the affected area, which restricts the development of injury. Furthermore, cryotherapy is also able to relieve the pain through a sensibility decrease of nocioceptive sensory nerves (10), which allows for the recovery of pain-free movements and accelerates the healing process. Despite the common application of cryotherapy, the physiological mechanisms of cryotherapy on rehabilitation are still unknown (11).

Thus, this systematic literature review about the effects of cryotherapy on circulatory, metabolic, inflammatory and neural aspects in humans is aimed at elucidating the physiological mechanisms related to the therapeutic effects of cryotherapy.

\section{Material and methods}

This systematic review involved a literature search on Pubmed, Scielo, PEDro and Scopus databases, with original studies written in English and/or Portuguese in the period between 1993 and 2012. Keywords used involved combinations of the following terms: criotherapy, spot cooling, thermal stress, cold exposure, cooling treatment, cooling muscle, muscle damage, 
secondary muscle injury, inflammation, blood flow, nerve conduction velocity, pain, water immersion and their corresponding words in Portuguese.

Inclusion criteria

Studies that met the following inclusion criteria were selected: (a) Randomized controlled trials (RCTs) that presented the effects of cryotherapy as an intervention on inflammatory markers, metabolism, circulation and pain; (b) Studies that performed comparative analysis between baseline and postintervention period; (c) Human sample with no sex restrictions; (d) Studies in which a key finding was blood flow, oxygen saturation, parameters related to pain and/or expression level of creatine kinase enzyme and myoglobin; (e) Studies with no influence of exercise on blood flow and/or oxygen saturation.

\section{Assessment of methodological quality}

Two authors independently rated the methodological quality of the included studies using the PEDro scale (12) that consists of 11-item points checklist. The goal was to identify the studies that have internal validity and sufficient statistical information. Each item found on studies adds one point in final score where the total score has a range from 0 to 10 points. An additional criteria (1) was used to assess the external validity (interpretability), but this was not counted in final score (12).

Total scores greater or equal than five points ( $50 \%$ of the evaluated points) in PEDro scale were considered in this systematic review as high methodological quality (13). In the case of studies involving cryotherapy, the blinding of therapists and/or subject is not feasible, which reduces the maximum score from 10 to 8 points. Thus, a five score covers $62 \%$ of all points and was considered a high quality methodological rate (13).

\section{Assessment of evidence level}

The methodological evaluation was analyzed by a classification of evidence levels which considered the total quality and results obtained (14). The following classification was adopted: Strong evidence when there were two or more high quality RCTs; Moderate evidence when there was one high quality RCT and one or more low-quality RCTs; Poor evidence when there was a single high or low quality RCT or multiple general consistent findings in controlled clinical trials; No evidence when there was no ERC or controlled clinical study.

\section{Results}

After screening the title/abstract of each article, 129 studies involving the use of cryotherapy were initially selected. However, only 13 studies met the inclusion criteria and were selected for this review (Figure 1).
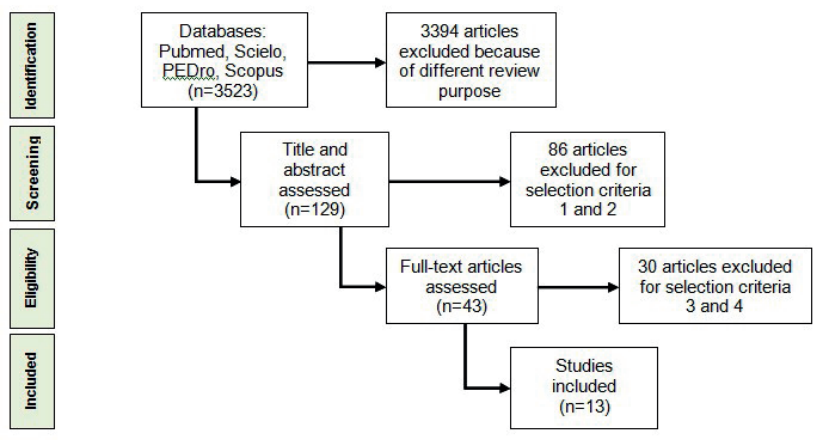

Figure $\mathbf{1}$ - Flow diagram of the literature screening process

Methodological quality

High methodological quality was observed in all included studies (Table 1). A total of 6 scores was observed in six studies (15 - 20), five studies (21 - 25) showed 5 scores, one study (26) reached 7 scores and one study (27) achieved 8 scores. Due to the limitation in using a single or double blind criteria for subjects and/or therapists (criteria 5 and 6) no study presented these items. The classification of methodological quality of included studies demonstrated a high level of evidence with consistent findings.

\section{Effects of cryotherapy methods}

Six studies evaluated the effects of cooling in blood flow (BF) $(21$ - 24, 26, 27), five evaluated the oxygen saturation $\left(\mathrm{SO}_{2}\right)$ and hemoglobin $(\mathrm{Hb})(22-26)$, four studies analyzed the post-capillary venous filling pressures (PCV) $(22-24,26)$ and three evaluated the neural conduction velocity (NCV) (17 - 19). The studies that assessed creatine kinase (CK) and myoglobin $(\mathrm{Mb})$ concentration $(15,16,20)$ conducted exercise 
protocols in order to increase the expression of these markers: Howatson et al. (15) used 3 sets of 10 eccentric contractions of elbow flexors in dynamometer; Bailey et al. (16) conducted 90 minutes of exercises that simulated the football gestures at an average intensity of $75 \% \mathrm{VO}_{2 \max }$; and Pournot et al. (20) used 2 sets of 10 minutes with exhaustive intermittent exercise consisting of vertical jumps and rowing exercise followed by 10-minute of resting interval between sets.

The sample size of the studies ranged from 7 to 30 participants in each group with 353 subjects evaluated in total. The time of cooling application ranged from 5 to 60 minutes, in which, nine studies used ice bag (17 - 19, 21-24, 26, 27), five used water immersion $(16,18-20,25)$ and three applied ice massage $(15,18,19)$. There were three studies that used more than one method simultaneously $(18,19,26)$. The main results were grouped according to the variables assessed, thus circulatory and metabolic parameters $\left(\mathrm{BF}, \mathrm{SO}_{2}, \mathrm{Hb}\right.$ and $\mathrm{PCV}$ ) are summarized in Table 2 and inflammatory and neural parameters (CK, Mb, VCN) are presented in Table 3.

All studies analyzed the immediate effects of cooling. Five studies assessing blood flow observed a decrease in this measure after cryotherapy (21-24, 26 ) and one did not find any significant change (27). The reductions ranged between $29.5 \%$ (21) and 91\% (26) in superficial regions (2-mm skin depths). In deep regions (8-mm skin depth), blood flow decrease ranged between $45 \%$ (23) and $74 \%(26)$.

In relation to oxygen saturation $\left(\mathrm{SO}_{2}\right)$ and hemoglobin ( $\mathrm{Hb})$, the studies observed a reduction on deep tissues (22-26). The superficial $\mathrm{SO}_{2}$ showed a decrease between $44 \%$ (23) and 64\% (26). The deep $\mathrm{SO}_{2}$ was significantly decreased by $4.4 \%$ in one study (24). Other studies did not observe any significant difference in deep $\mathrm{SO}_{2}(22,23,26)$. The $\mathrm{Hb}$ was used to measure $\mathrm{SO}_{2}$, and in one study (25) a reduction of $5100 \%$ was observed.

Four studies evaluated the post-capillary venous filling pressures (PCV) and observed significant reductions in superficial and deep regions. All studies, except one (24), had larger decreases in superficial PCV when compared to the deep PCV. The decrease rate in superficial region ranged between 14\% (24) and $36.6 \%$ (24), whereas in deep region a decrease rate between $8 \%$ (22 patients) and $22.5 \%$ was observed (23).

In relation to the levels of inflammatory markers, studies used exercise protocols to induce increase in these markers followed by cryotherapy. All studies observed an increase in CK enzyme after exercise protocols $(15,16,20)$. Two studies observed no significant difference after cryotherapy treatment compared to a control group $(15,16)$ and one study observed lower CK expression after cryotherapy (20). In relation to $\mathrm{Mb}$, one study found no difference between cryotherapy group and control group (15), while a second study observed Mb expression decrease in cryotherapy group (16).

The studies analyzed in this review involving cooling effects on NCV did not conduct exercise before or after cryotherapy treatment. All studies found

Table 1- Quality assessment with PEDro scale

(To be continued)

\begin{tabular}{|c|c|c|c|c|c|c|c|c|c|c|c|c|}
\hline Authors & $1^{*}$ & 2 & 3 & 4 & 5 & 6 & 7 & 8 & 9 & 10 & 11 & Score \\
\hline Ho et al. (23) & $\sqrt{ }$ & & & $\sqrt{ }$ & & & & $\sqrt{ }$ & $\sqrt{ }$ & $\sqrt{ }$ & $\sqrt{ }$ & 5 \\
\hline Howatson et al. (17) & & $\sqrt{ }$ & & $\sqrt{ }$ & & & & $\sqrt{ }$ & $\sqrt{ }$ & $\sqrt{ }$ & $\checkmark$ & 6 \\
\hline Knoblock et al. (24) & $\sqrt{ }$ & & & $\sqrt{ }$ & & & & $\sqrt{ }$ & $\sqrt{ }$ & $\sqrt{ }$ & $\sqrt{ }$ & 5 \\
\hline Knoblock et al. (25) & $\sqrt{ }$ & & & $\sqrt{ }$ & & & & $\sqrt{ }$ & $\sqrt{ }$ & $\sqrt{ }$ & $\sqrt{ }$ & 5 \\
\hline Knoblock et al. (26) & $\sqrt{ }$ & & & $\sqrt{ }$ & & & & $\sqrt{ }$ & $\sqrt{ }$ & $\sqrt{ }$ & $\sqrt{ }$ & 5 \\
\hline Yanagisawa et al. (27) & & & & $\sqrt{ }$ & & & & $\sqrt{ }$ & $\sqrt{ }$ & $\sqrt{ }$ & $\sqrt{ }$ & 5 \\
\hline Bailey et al. (18) & & $\sqrt{ }$ & & $\sqrt{ }$ & & & & $\sqrt{ }$ & $\sqrt{ }$ & $\sqrt{ }$ & $\sqrt{ }$ & 6 \\
\hline Algafly e Geroge (19) & $\sqrt{ }$ & $\sqrt{ }$ & & $\sqrt{ }$ & & & & $\sqrt{ }$ & $\sqrt{ }$ & $\sqrt{ }$ & $\sqrt{ }$ & 6 \\
\hline Knoblock et al. (28) & $\sqrt{ }$ & $\sqrt{ }$ & $\sqrt{ }$ & $\sqrt{ }$ & & & & $\sqrt{ }$ & $\sqrt{ }$ & $\sqrt{ }$ & $\sqrt{ }$ & 7 \\
\hline Herrera et al. (20) & $\sqrt{ }$ & $\sqrt{ }$ & & $\sqrt{ }$ & & & & $\sqrt{ }$ & $\sqrt{ }$ & $\sqrt{ }$ & $\sqrt{ }$ & 6 \\
\hline
\end{tabular}


Table 1- Quality assessment with PEDro scale

(Conclusion)

\begin{tabular}{lcccccccccccc}
\hline Authors & $\mathbf{1}^{*}$ & $\mathbf{2}$ & $\mathbf{3}$ & $\mathbf{4}$ & $\mathbf{5}$ & $\mathbf{6}$ & $\mathbf{7}$ & $\mathbf{8}$ & $\mathbf{9}$ & $\mathbf{1 0}$ & $\mathbf{1 1}$ & Score \\
\hline Herrera et al. (21) & $\sqrt{ }$ & $\sqrt{ }$ & & $\sqrt{ }$ & & & & $\sqrt{ }$ & $\sqrt{ }$ & $\sqrt{ }$ & $\sqrt{ }$ & 6 \\
\hline Pournot et al. (22) & & $\sqrt{ }$ & & $\sqrt{ }$ & & & & $\sqrt{ }$ & $\sqrt{ }$ & $\sqrt{ }$ & $\sqrt{ }$ & 6 \\
\hline Selkow et al. (29) & $\sqrt{ }$ & $\sqrt{ }$ & $\sqrt{ }$ & $\sqrt{ }$ & & & $\sqrt{ }$ & $\sqrt{ }$ & $\sqrt{ }$ & $\sqrt{ }$ & $\sqrt{ }$ & 8 \\
\hline
\end{tabular}

Note: Legend: Question 1 = eligibility criteria ( ${ }^{*}$ not accounted); Question 2 = random allocation; Question 3 = concealed allocation; Question 4 = baseline comparability; Question $5=$ participants blinded; Question $6=$ therapists blinded; Question $7=$ assessors blinded; Question 8 = follow-up in $>85 \%$ of participants; Question $9=$ All participants receive treatment or control condition; Question $10=$ between group analysis; Question $11=$ accuracy measures

Table 2 - Effects of cryotherapy on circulatory and metabolic parameters

\begin{tabular}{|c|c|c|c|c|c|c|}
\hline \multirow[b]{2}{*}{ Author } & \multirow[b]{2}{*}{ Method } & \multirow[b]{2}{*}{ Groups/Time } & \multirow[b]{2}{*}{ Variables (Unit) } & \multicolumn{3}{|c|}{ Results } \\
\hline & & & & Baseline & $\begin{array}{c}\text { Post - treat- } \\
\text { ment }\end{array}$ & $\begin{array}{l}\text { Difference } \\
\text { (\%) }\end{array}$ \\
\hline \multirow{5}{*}{ Ho et al. (23) } & \multirow{5}{*}{ Ice pack } & $5^{\prime} \quad(n=8)$ & & 100 & 88.9 & $\downarrow 11.1^{*}$ \\
\hline & & $10^{\prime}(n=8)$ & & 100 & 88.7 & $\downarrow 11.3^{*}$ \\
\hline & & $15^{\prime}(\mathrm{n}=8)$ & $\mathrm{DBF}(\%)$ & 100 & 83.7 & $\downarrow 16.3^{*}$ \\
\hline & & $20^{\prime}(\mathrm{n}=7)$ & & 100 & 74.5 & $\downarrow 25.5^{*}$ \\
\hline & & $25^{\prime}(n=7)$ & & 100 & 70.5 & $\downarrow 29.5^{*}$ \\
\hline \multirow{3}{*}{ Knobloch et al. (24) } & \multirow{3}{*}{$\begin{array}{l}\text { Ice pack and } \\
\text { compression }\end{array}$} & \multirow{3}{*}{$30^{\prime}(n=21)$} & $\mathrm{SSO}^{2}$ e $\mathrm{DSO}^{2}(\%)$ & 48 e 69 & 23 e 69 & $\downarrow 52^{\star}$ e 0 \\
\hline & & & SPCV e DCVP (UN) & 61 e 85 & 42 e 78 & $\downarrow 31.14^{\star}$ e 8.23 \\
\hline & & & SBF e DBF (UN) & 21 e 63 & 7 e 39 & $\downarrow 66.6^{\star}$ e $38^{\star}$ \\
\hline \multirow{3}{*}{ Knobloch et al. (25) } & \multirow{3}{*}{$\begin{array}{l}\text { Ice pack and } \\
\text { compression }\end{array}$} & \multirow{3}{*}{$30^{\prime}(n=26)$} & $\mathrm{SSO}^{2}$ e DSO${ }^{2}(\%)$ & 35.9 e 66.4 & 20 e 64.6 & $\downarrow 44.3^{*}$ e 2.7 \\
\hline & & & SPCV e DPCV (UN) & 41.3 e 53.2 & 26.4 e 41.2 & $\downarrow 36.1^{\star}$ e $22.5^{\star}$ \\
\hline & & & SBF e DBF (UN) & 48.4 e 197.2 & 8.3 e 106.4 & $\downarrow 83^{\star}$ e $46^{\star}$ \\
\hline Yanagisawa et al. (27) & $\begin{array}{c}\text { Water } \\
\text { immersion } \\
\left(0^{\circ} \mathrm{C}\right) .\end{array}$ & $30^{\prime}(n=10)$ & $\mathrm{Hb}(\Delta \mathrm{umol} / \mathrm{L})$ & 0.8 & -40 & $\downarrow 5100^{*}$ \\
\hline \multirow{6}{*}{ Knobloch et al. (28) } & \multirow{6}{*}{ Ice pack } & \multirow{6}{*}{$\begin{array}{c}30 ': \\
\text { (1) compression } \\
(n=30) \\
(2) \text { no } \\
\text { compression } \\
(n=30)\end{array}$} & $\mathrm{SSO}^{2}(\%)$ & $\begin{array}{c}36(1) \text { e } \\
42(2)\end{array}$ & 15 e 15 & $\downarrow 58.3^{\star}$ e $64.3^{\star}$ \\
\hline & & & $\mathrm{DSO}^{2}(\%)$ & $\begin{array}{l}65(1) \mathrm{e} \\
68(2)\end{array}$ & 64 e 68 & $\downarrow 1.5$ e 0 \\
\hline & & & SPCV (UN) & $\begin{array}{c}40(1) \mathrm{e} \\
41(2)\end{array}$ & 29 e 28 & $\downarrow 27.5^{\star}$ e $31.7^{\star}$ \\
\hline & & & DPCV (UN) & $\begin{array}{l}51(1) \mathrm{e} \\
56(2)\end{array}$ & 41 e 47 & $\downarrow 19.6^{\star}$ e $16^{*}$ \\
\hline & & & SBF (UN) & $\begin{array}{l}43(1) \mathrm{e} \\
42(2)\end{array}$ & 4 e 4 & $\downarrow 90.6^{\star}$ e $90.5^{\star}$ \\
\hline & & & $\mathrm{DBF}(\mathrm{UN})$ & $\begin{array}{c}178(1) \mathrm{e} \\
180(2) \\
\end{array}$ & 46 e 56 & $\downarrow 74.1^{\star}$ e $69^{*}$ \\
\hline \multirow[t]{2}{*}{ Selkow et al. (29) } & \multirow[t]{2}{*}{ Ice pack } & \multirow{2}{*}{$\begin{array}{l}\text { 10-60: } \\
\text { intervention } \\
(n=19) \\
\text { control }(n=19)\end{array}$} & \multirow[t]{2}{*}{$\mathrm{BF}\left(\mathrm{dB} \cdot \mathrm{s}^{-1}\right)$} & 3.1 & 2.8 & $\downarrow 9.6$ \\
\hline & & & & 2.6 & 3.4 & $\uparrow 30.7^{\star}$ \\
\hline \multicolumn{7}{|c|}{$\begin{array}{l}\text { Note: } \mathrm{SBF}=\text { superficial blood flow; } \mathrm{DBF}=\text { deep blood flow; } \mathrm{SSO2}=\text { superficial oxygen saturation; } \mathrm{DSO2}=\text { deep oxygen saturation; } \mathrm{SPCV}= \\
\text { superficial postcapillary venous filling pressures; } \mathrm{DPCV}=\text { deep postcapillary venous filling pressures; } \mathrm{Hb}=\text { hemoglobin. } \\
\text { *Difference between post-treatment and baseline }\end{array}$} \\
\hline
\end{tabular}


Table 3 - Effects of cryotherapy on inflammatory and neural parameters

\begin{tabular}{|c|c|c|c|c|c|c|}
\hline \multirow{2}{*}{ Author } & \multirow{2}{*}{ Method } & \multirow{2}{*}{ Groups } & \multirow[b]{2}{*}{$\begin{array}{c}\text { Variables } \\
\text { (Unit) }\end{array}$} & \multicolumn{3}{|c|}{ Results } \\
\hline & & & & Baseline & $\begin{array}{c}\text { Post - } \\
\text { treatment }\end{array}$ & $\begin{array}{c}\text { Difference } \\
\text { (\%) }\end{array}$ \\
\hline \multirow{2}{*}{$\begin{array}{l}\text { Howatson et al. } \\
\text { (17) }\end{array}$} & \multirow{2}{*}{$\begin{array}{c}\text { Ice massage; } \\
15^{\prime} .\end{array}$} & Exercise $(n=12)$ & \multirow{2}{*}{$\begin{array}{l}\text { CK (IU/L) and } \\
\text { Mb (ng/L) }\end{array}$} & 4.9 e 4 & 6 e 5.2 & $\uparrow 22.4^{*}$ e $30^{*}$ \\
\hline & & Exercise + Intervention $(n=12)$ & & 5 e 3.7 & 5.5 e 5.2 & $\uparrow 10^{*}$ e $40.5^{*}$ \\
\hline \multirow{2}{*}{ Bailey et al. (18) } & \multirow{2}{*}{$\begin{array}{c}\text { Water } \\
\text { immersion } \\
\left(10^{\circ} \mathrm{C}\right) ; 10^{\prime} \text {. }\end{array}$} & Exercise + Intervention $(n=10)$ & \multirow{2}{*}{$\begin{array}{l}\text { CK }\left(U . L^{-1}\right) \text { and } \\
\operatorname{Mb}\left(n m o l . L^{-1}\right)\end{array}$} & 290 e 5 & 1250 e 30 & $\uparrow 331^{\star}$ e $500^{\star} \#$ \\
\hline & & Exercise $(n=10)$ & & 450 e 5 & 1400 e 45 & $\uparrow 211^{\star}$ e $800^{*}$ \\
\hline \multirow{2}{*}{$\begin{array}{l}\text { Pournot et al. } \\
\text { (22) }\end{array}$} & \multirow{2}{*}{$\begin{array}{c}\text { Water } \\
\text { immersion } \\
\left(10^{\circ} \mathrm{C}\right) ; 15^{\prime} \text {. }\end{array}$} & Exercise + Intervention $(n=13)$ & \multirow{2}{*}{ CK (U/L) } & 450 & 600 & $\uparrow 33.3$ \\
\hline & & Exercise $(n=9)$ & & 460 & 810 & $\uparrow 76^{*}$ \\
\hline \multirow{2}{*}{$\begin{array}{l}\text { Algafly e George } \\
\text { (19) }\end{array}$} & \multirow{2}{*}{ Ice pack; 26'. } & Control $(n=23)$ & \multirow{2}{*}{$\mathrm{NCV}(\mathrm{m} / \mathrm{s})$} & 34.8 & 34.6 & $\downarrow 0.5$ \\
\hline & & Intervention $(\mathrm{n}=23)$ & & 34.9 & 23.45 & $\downarrow 32.8^{*}$ \\
\hline \multirow{3}{*}{ Herrera et al. (20) } & \multirow{3}{*}{$\begin{array}{c}\text { Three } \\
\text { methods; 15'. }\end{array}$} & Ice pack $(n=12)$ & \multirow{3}{*}{$\begin{array}{l}\text { NCV }(\mathrm{m} / \mathrm{s}) \\
\text { posterior tibial } \\
\text { and sural } \\
\text { nerves }\end{array}$} & $\begin{array}{c}48.58 \mathrm{e} \\
52.42\end{array}$ & 47.5 e 35.67 & $\downarrow 2.2^{\star}$ e $31.9^{*}$ \\
\hline & & Ice massage $(n=12)$ & & $\begin{array}{c}49.67 \mathrm{e} \\
53.92\end{array}$ & 47.17 e 33.5 & $\downarrow 5^{\star}$ e $37.8^{\star}$ \\
\hline & & Water immersion $10^{\circ} \mathrm{C}(\mathrm{n}=12)$ & & 49 e 54.08 & 40.67 e 31.5 & $\downarrow 17^{\star} \#$ e $41.7^{\star} \#$ \\
\hline \multirow{3}{*}{ Herrera et al. (21) } & \multirow{3}{*}{$\begin{array}{c}\text { Three } \\
\text { methods; } 15 \text { '. }\end{array}$} & Ice pack $(n=12)$ & \multirow{3}{*}{$\begin{array}{l}\text { NCV }(\mathrm{m} / \mathrm{s}) \\
\text { posterior tibial } \\
\text { and sural } \\
\text { nerves }\end{array}$} & $\begin{array}{l}50.2 \mathrm{e} \\
51.5\end{array}$ & 44.7 e 44.5 & $\downarrow 11^{\star}$ e $13.5^{\star}$ \\
\hline & & Ice massage $(n=12)$ & & $\begin{array}{c}50.3 \mathrm{e} \\
53.7\end{array}$ & 45.7 e 45.7 & $\downarrow 9^{*}$ e $14.8^{*}$ \\
\hline & & Water immersion $10^{\circ} \mathrm{C}(\mathrm{n}=12)$ & & $\begin{array}{c}49.7 \mathrm{e} \\
54.8\end{array}$ & 40 e 39.5 & $\downarrow 19.5^{\star} \#$ e $28^{\star} \#$ \\
\hline
\end{tabular}

Note: $\mathrm{CK}=$ creatina kinase; $\mathrm{Mb}=$ mioglobin; $\mathrm{NCV}=$ neural conduction velocity

*Difference between post-treatment and baseline

\#Difference between groups

reductions on NCV rates after cryotherapy, which ranged between $2.2 \%$ and $41.7 \%$ (17-19).

\section{Discussion}

The level of evidence discussed in systematic reviews is related to methodological quality of included studies. The methodological quality assessment revealed high quality of all included studies. The results of this review are discussed from findings of the studies with high methodological quality and strong evidence.

\section{Circulatory and metabolic parameters}

BF obtained the largest changes induced by cryotherapy. This variable was evaluated by triple-phase bone scans (21) a laser doppler spectrophotometry system $(22-24,26)$ or microvascular perfusion with ultrasound machine (27). Five studies reported a significant reduction after cryotherapy intervention $(21-24,26)$. The studies used ice pack associated or not to compression and obtained a decrease of $91 \%$ in superficial and 74\% in deep regions. Application time ranged between 5 and 30 minutes; however, Ho et al. (21) observed correlation between cryotherapy time of application and BF decrease. The longer cryotherapy treatment (25 minutes) had larger BF decreases compared with the shortest treatment time (5 minutes) (21).

The BF reduction may result from vasoconstriction. Previous authors related that vasoconstriction is an important physiological response to thermal homeostasis and a thermal protection during cold exposure, since BF increase causes higher heat loss from blood (28). Another study reported that neural reflexes are the main agents responsible for immediate vasoconstriction response to local cooling 
through adrenergic elements (29). The exact physiological mechanism induced by cryotherapy to promote vasoconstriction is unknown, but this response is well documented in the literature. Thorlacius et al. (30) observed arteriolar vasoconstriction with vessel diameter decrease by an average of $7 \%$, while the percentage of capillaries with no BF increased ranged from $0.5 \%$ to $14 \%$ after 10 minutes of cryotherapy. Yanagisawa et al. (31) showed suppression of water molecules movement and muscle microcirculation after cryotherapy. The vasoconstriction induced by cold treatment is important to reduce BF and control cellular environment at the lowest possible damage scenario, as in situations of surgical procedure (2), edema formation (32) or muscle injury (33).

One study reported no effect on BF after ice pack application even with a tissue temperature decrease to $7^{\circ} \mathrm{C}(27)$. However, it is important to state that the control group presented BF increases and cryotherapy group maintained BF level without differences. According to the authors, this response was due to the trauma induced by placing an intramuscular sensor, which may have increased local temperature, while cryotherapy group did not present temperature changes. Thus, cryotherapy induced a reduction in $\mathrm{BF}$ even after microlesion.

In relation to $\mathrm{SO}_{2}$ and $\mathrm{Hb}$ concentration, five studies (22-26) identified similar results using spectrometry method with application of ice pack mixed with water at temperatures between $0^{\circ}$ and $15^{\circ} \mathrm{C}$ during 30 minutes. The $\mathrm{Hb}$ is a protein that carries oxygen molecule into the blood (34) and the Hb concentration reflects oxygenation level, which was used to measure local $\mathrm{SO}_{2}$. The studies assessed in the present review reported a decrease at superficial regions after cryotherapy for $\mathrm{SO}_{2}$ and $\mathrm{Hb}$ concentration. Interestingly, the studies with no compression association showed larger reduction in saturation levels at superficial region compared to cryotherapy associated with compression $(23,24,26)$. Although the authors did not explain their findings, it is possible to infer that the compression can cause occlusion in blood vessels which affects blood flow and, consequently, $\mathrm{Hb}$ concentration at the superficial region.

At deep regions $(8 \mathrm{~mm})$, three studies reported no significant difference in $\mathrm{SO}_{2}(22,23,26)$ and one study (24) observed a small significant decrease of $4.4 \%$. The $\mathrm{BF}$ and $\mathrm{SO}_{2}$ relation is not proportional, and studies have identified large reductions in $\mathrm{BF}$ at deep regions with no oxygen changes. Even with a
BF decrease caused by vasoconstriction, the $\mathrm{Hb}$ and oxygen concentration is not affected at deep regions. This mechanism can be secondary as a body response in order to sustain longer oxygen supply at deep tissues, even with BF decreases. These results can suggest a protection for deep tissues with decrease in $\mathrm{BF}$, sustaining oxygen supply.

The changes in oxygen and nutrients supply to tissues compromise mitochondria and energy production. When injury occurs, the increased demand for oxygen from cells for its regenerative functions together with the limited oxygen supply, contribute to excessive free radicals production, which affect mitochondria function (35). The $\mathrm{SO}_{2}$ decrease means that cells are using a smaller amount of oxygen to perform its function (36). In this context, cryotherapy can reduce secondary damage from metabolic changes caused by injury. Cryotherapy reduces the need for oxygen at tissues (2, 6) and important organelles as mitochondria (7).

All studies that evaluated PCV observed significant reductions at superficial and deep regions (22-24, $26)$. These findings highlighted a $36.1 \%$ decrease at the superficial region and $22.5 \%$ at the deep region (23). The capillaries BF decrease is interesting since it avoids a blockage of venous return flow, which can prevent thrombus formation or other circulatory abnormalities (26). In addition, BF decrease also reduces the liquid accumulation in tissues and edema formation. Three studies $(23,24,26)$ used three series with 10-minute of cryotherapy alternated with 10-minute of rest between series. These studies observed different PCV results which led to larger decreases in different series of cryotherapy $(23,24,26)$. Although the authors did not explain these results, the pressure adjustment of the muscles' capillaries as a response to cold exposure might be an explanation for this finding.

\section{Inflammatory and neural parameters}

The inflammatory response induced by exercise is a protective vascular tissue response mechanism to injury (37). The studies that assessed inflammatory markers observed tissue damage by physical exercise. Despite the different methodologies, the exercise protocols used in the included studies highlighted increases in CK and Mb expression. Two studies (15, 16) evaluated the expression of CK and found no difference between cryotherapy and no cryotherapy groups at 24 and 96 hours post-exercise. However, 
Pournot et al. (20) observed that the control group increased CK concentration $24 \mathrm{~h}$ post-exercise, while the cryotherapy group showed no significant difference. The reviewed studies applied ice massage for 15 minutes (15) and water immersion for 10 (16) and 15 minutes (20) as cryotherapy intervention. The positive finding of Pournot et al. (20) appears to be associated with a less intense exercise protocol and to water immersion intervention for 15 minutes, which is a possible explanation for the effects on CK, but results of the three studies are inconclusive.

The expression of $\mathrm{Mb}$ was observed in two studies $(15,16)$. Bailey et al. (16) observed Mb expression decreases in cryotherapy group $1 \mathrm{~h}$ post-exercise compared to a control group, while Howatson et al. (15) observed no difference between cryotherapy and control groups $96 \mathrm{~h}$ post-exercise. On the other hand, the second study did not measure $\mathrm{Mb} 1 \mathrm{~h}$ post-exercise and the first study did not measure $96 \mathrm{~h}$ post-exercise, thus it is not possible to compare the findings between studies or effects between water immersion (16) and ice massage (15). Therefore, the results are inconclusive.

When an injury occurs, the release of substances from damaged cells activates the production of inflammatory chemical mediators (38). These mediators are involved in enzymatic changes related to pro-inflammatory enzymes released as acid hydrolases, phospholipases, proteases and neutrophils (3). These substances are responsible for attracting more circulating inflammatory cells as neutrophils and macrophages (36). Neutrophils had an important role in degradation of damaged cells produced by primary injury (39); however, their oxidative reactions promote cytokines release which activates inflammatory cells and increased production of free radicals. This reaction causes damage to cellular membrane resulting in increased injury (37). Thus, restrictions in inflammation process as lowering the concentration of oxidants derived from neutrophils can reduce the tissue damage (40). Large increases in CKand $\mathrm{Mb}$ expression are indicators of damage caused by the inflammatory process; however, included studies are inconclusive about cryotherapy efficiency in containing the expression of these substances.

The NCV is a parameter related to analgesic properties, since the speed of nociceptive sensory pathways transmission is reduced by local cooling (17-19). Herrera et al. (18) and Herrera et al. (19) observed a significant NCV decrease after cryotherapy in posterior tibial (motor) and sural (sensory) nerves. In addition, the results of these studies suggests that water immersion method had better efficiency compared to ice massage and ice pack, even with none achieving the highest cooling values at a time of 15 minutes. This finding from water immersion can result from a larger contact area of the cold method achieving greater nerve pathways, when ice pack and ice massage affect a limited area. Furthermore, Algafly and George (17) reported that the cryotherapy group led to NCV decreases and increases in pain threshold (between $71 \%$ and $89 \%$ ) and tolerance (56\% from and $76 \%$ ) compared to a control group.

Cryotherapy also induces local effects and influences the spinal cord level effects through neurological mechanisms (10). The cold method increases the activation of nociceptors threshold and decreases NVC of pain signals causing local anesthesia (10). However, the cooling level to obtain these effects cannot be maximum. Herrera et al. (18) observed that the higher cooling is not necessary to obtain better therapeutic effects in nerve tissue. Thus, it is important that more studies assess the cryotherapy effects on neural structures.

The present study has limitations that should be stated. First, we did not consider for analysis the articles written in languages different from English and Portuguese. The native language of the authors is Portuguese and the scientific publication was predominantly written in English language; thus, the selection process bias should not compromise the findings and discussion of the present review. Second, the included studies presented different methodologies and different methods for data analysis, which precluded the development of a meta-analysis. Finally, future research on cryotherapy methods in specific injuries and musculoskeletal tissue inflammation are needed to assess the effects on other clinical condition different from damages induced by exercise experimental models.

\section{Conclusion}

The present review showed that cryotherapy methods decreases significantly BF and PCV, reduces oxygen saturation and hemoglobin level at superficial region and reduces NCV. Despite different procedures in relation to time or application method, all methods of cryotherapy were effective. The effects of cryotherapy on inflammatory markers release remain 
inconclusive; however, the physiological responses to cryotherapy suggests the use of this therapeutic tool as treatment for inflammatory processes and pain decreases in rehabilitation of the neuromuscular system injuries.

\section{References}

1. Bleakley CM, Davinson GW. Cryotherapy and inflammation: evidence beyond the cardinal signs. Phys Ther Rev. 2010;15(6):430-5.

2. Knight KL. Crioterapia no tratamento das lesões esportivas. São Paulo: Manole; 2000.

3. Merrick MA. Secondary injury after muscoloskeletal injury trauma: A review and update. J Athl Train. 2002;37(2):209-17.

4. Ghaly A, Marsh DR. Ischaemia-reperfusion modulates inflammation and fibrosis of skeletal muscle after contusion injury. Int J Exp Path. 2010;91:244-55.

5. Bélanger A. Evidence-based guide to therapeutic physical agents. Philadelphia: Lippincott Williams \& Wilkins; 2002.

6. Schaser KD, Disch AC, Stover JF, Lauffer A, Bail HJ, Mittlmeier T. Prolonged superficial local cryotherapy attenuates microcirculatory impairment, regional inflammation, and muscle necrosis after closed soft tissue injury in rats. Am J Sports Med. 2007;35(1):93-102.

7. Puntel GO, Carvalho NR, Amaral GP, Lobato LD, Silveira O, Daubermann MF, et al. Therapeutic cold: An effective kind to modulate the oxidative damage resulting of a skeletal muscle contusion. Free Radic Res. 2011;45(2):125-38.

8. Thorsson 0. Cold therapy of athletic injuries. Current literature review. Lakartidningen. 2001;98(13):1512-3.

9. Karunakara RG, Lephart SM, Pincivero DM. Changes in Forearm Blood Flow During Single and Intermittent Cold Application. J Orthop Sports Phys Ther. 1999;29(3):177-80.

10. Nadler SF, Weingand K, Kruse RJ. The Physiologic Basis and Clinical Applications of Cryotherapy and Thermotherapy for the Pain Practitioner. Pain Physician . 2004;7:395-9.
11. Hubbard TJ, Denegar CR. Does Cryotherapy Improve Outcomes With Soft Tissue Injury? J Athl Train. 2004 Sep;39(3):278-9.

12. PEDro Scale. The Physiotherapy Evidence Database (PEDro)[internet] 2012 [cited 2012 SeP. 10]. Available from: URL: www.pedro.org.au/portuguese.

13. Moseley AM, Herbert RD, Sherrington C, Maher CG. Evidence for physiotherapy practice: a survey of the Physiotherapy Evidence Database (PEDro). Aust J Physiother. 2002;48(1):43-9.

14. Van Tulder M, Furlan A, Bombardier C, Bouter L. Editorial Board of the Cochrane Collaboration Back Review Group. Updated method guidelines for systematic reviews in the Cochrane Collaboration Back Review Group. Spine. 2003;28(12):1290-3.

15. Howatson G, Gaze D, Van Someren KA. The efficacy of ice massage in the treatment of exerciseinduced muscle damage. Scand J Med Sci Sports. 2005;15(6):416-22.

16. Bailey DM, Erith SJ, Griffin PJ, Dowson A, Brewer DS, Gant N, et al. Influence of cold-water immersion on indices of muscle damage following prolonged intermittent shuttle running. J Sports Sci. 2007;25(11):1163-70.

17. Algafly AA, George KP. The effect of cryotherapy on nerve conduction velocity, pain threshold and pain tolerance. Br J Sports Med. 2007;41:365-9.

18. Herrera E, Sandoval MC, Camargo DM, Salvini TF. Motor and sensory nerve conduction are affected differently by ice pack, ice massage, and cold water immersion. Phys Ther. 2010;90:581-91.

19. Herrera E, Sandoval MC, Camargo DM, Salvini TF. Effect of walking and resting after three cryotherapy modalities on the recovery of sensory and motor nerve conduction velocity in healthy subjects. Rev Bras Fisioter. 2011;15(3):233-40.

20. Pournot H, Bieuzen F, Duffield R, Lepretre PM, Cozzolino $C$, Hausswirth C. Short term effects of various water immersions on recovery from exhaustive intermittent exercise. Eur J Appl Physiol. 2011;111(7):1287-95.

21. Ho SS, Illgen RL, Meyer RW, Torok PJ, Cooper MD, Reider B. Comparison of various icing times in decreasing bone metabolism and blood flow in the knee. Am J Sports Med. 1995;23(1):74-6. 
22. Knobloch K, Kraemer R, Lichtenberg A, Jagodzinski M, Gosling T, Richter M, et al. Microcirculation of the ankle after Cryo/Cuff application in healthy volunteers. Int J Sports Med. 2006a;27(3):250-5.

23. Knobloch K, Grasemann R, Jagodzinski M, Richter M, Zeichen J, Krettek C. Changes of Achilles midportion tendon microcirculation after repetitive simultaneous cryotherapy and compression using a Cryo/Cuff. Am J Sports Med. 2006b;34(12):1953-59.

24. Knobloch K, Grasemann R, Spies M, Vogt PM. Intermittent KoldBlue cryotherapy of 3x10 min changes mid-portion Achilles tendon microcirculation. Br J Sports Med. 2007;41(6):e4.

25. Yanagisawa O, Homma T, Okuwaki T, Shimao D, Takahashi H. Effects of cooling on human skin and skeletal muscle. Eur J Appl Physiol. 2007;100(6):737-45.

26. Knobloch K, Grasemann R, Spies M, Vogt PM. Midportion Achilles tendon microcirculation after intermittent combined cryotherapy and compression compared with cryotherapy alone: a randomized trial. Am J Sports Med. 2008;36(11):2128-38.

27. Selkow NM, Day C, Liu Z, Hart JM, Hertel J, Saliba SA. Microvascular perfusion and intramuscular temperature of the calf during cooling. Med Sci Sports Exerc. 2012;44(5):850-6.

28. Yamazaki F, Sone R, Zhao K, Alvarez GE, Kosiba WA, Johnson JM. Rate dependency and role of nitric oxide in the vascular response to direct cooling in human skin. J Appl Physiol. 2006;100(1):42-50.

29. Johnson JM, Yen TC, Zhao K, Kosiba WA. Sympathetic, sensory, and nonneuronal contributions to the cutaneous vasoconstrictor response to local cooling. Am J Physiol Heart Circ Physiol. 2005;288(4):1573-9.

30. Thorlacius H, Vollmar B, Westermann S, Törkvist L, Menger MD. Effects of local cooling on microvascular hemodynamics and leukocyte adhesion in the striated muscle of hamsters. J Trauma. 1998;45(4):715-9.

31. Yanagisawa O, Takahashi H, Fukubayashi T. Effects of different cooling treatments on water diffusion, microcirculation, and water content within exercised muscles: evaluation by magnetic resonance T2weighted and diffusion-weighted imaging. J Sports Sci. 2010;28(11):1157-63.
32. Yanagisawa O, Kudo H, Takahashi N, Yoshioka H. Magnetic resonance imaging evaluation of cooling on blood flow and edema in skeletal muscles after exercise. Eur J Appl Physiol. 2004;91(5-6):737-40.

33. Lee H, Natsui H, Akimoto T, Yanagi K, Ohshima N, Kono I. Effects of cryotherapy after contusion using real-time intravital microscopy. Med Sci Sports Exerc. 2005;37(7):1093-8.

34. Nelson DL, Cox MM. Lehninger, Principles of Biochemistry. 4nd ed. New York: Worth Publishers; 2004.

35. Honda HM, Korge P, Wiess JN. Mitochondria and ischemia/reperfusion injury. Ann N Y Acad Sci. 2005;1047:248-58.

36. Guyton AC, Hall JE. Tratado de Fisiologia Médica. 11 a ed. Rio de Janeiro: Elsevier; 2006.

37. Toumi H, F'Guyer S, Best TM. The role of neutrophils in injury and repair following muscle stretch. J Anat. 2006;208(4):459-70.

38. Porth CM, Matfin G. Fisiopatologia. 8 ${ }^{\underline{a}}$ ed. Rio de Janeiro: Guanabara Koogan, 2010.

39. Tidball JG. Inflammatory processes in muscle injury and repair. Am J Physiol Regul Integr Comp Physiol. 2005;288:345-53.

40. St. Pierre Schneider B, Brickson S, Corr DT, Best TM. CD11b+ neutrophils predominate over RAM11+ macrophages in stretch-injured muscle. Muscle Nerve. 2002;25:837-44.
Receveid:02/13/2015

Recebido: 13/02/2015 Aprovado: 19/06/2015 Approved:06/19/2015 